\title{
Ecology and Hybridization Potential of Two Sympatric Metallophytes, the Narrow Endemic Crepidorhopalon perennis (Linderniaceae) and its More Widespread Congener C. tenuis
}

\author{
Michel-Pierre Faucon ${ }^{1,2,7}$, Benedict M. Tshilong ${ }^{3}$, Fabienne Van Rossum ${ }^{4}$, Pierre Meerts ${ }^{1}$, Guillaume Decocq ${ }^{5}$, and Grégory Mahy ${ }^{6}$ \\ ${ }^{1}$ Laboratoire d'Ecologie végétale et Biogéochimie, Université Libre de Bruxelles, Boulevard du Triomphe, B-1050 Bruxelles, Belgium \\ 2 Hydrogéochimie Interactions Sol-Environnement (HydrISE), Institut Polytechnique LaSalle Beauvais (IGAL-ISAB), rue Pierre Waguet 19 - \\ BP 30313, F-60026 Beauvais, France \\ ${ }^{3}$ Université de Lubumbashi, Faculté des Sciences Agronomiques, Lubumbashi, Democratic Republic of Congo \\ ${ }^{4}$ Department of Vascular Plants, National Botanic Garden of Belgium, Domein van Bouchout, B-1860 Meise, Belgium \\ ${ }^{5}$ Dynamique des Systèmes Anthropisés, Université de Picardie Jules Vernes, Faculté de Pharmacie, rue des Louvels 1, F-80037 Amiens \\ Cedex 1, France \\ ${ }^{6}$ Laboratory of Ecology, Université de Liège, Gembloux Agro-Bio Tech, Passage des Déportés 2, B-5030 Gembloux, Belgium
}

\begin{abstract}
Crepidorhopalon perennis is a metallophyte critically endangered by mining activities and currently known from only one site on copper-rich soils in Katanga (Dem. Rep. Congo). It is closely related to the annual C. tenuis, also a rare metallophyte, but with a broader geographical range. We investigated the variation in morphometric traits and ecological niches (based on edaphic conditions and pollinator assemblages) of $C$. perennis and $C$. tenuis, to evaluate the risk of inter-specific competition, and their potential for hybridization to ascertain if C. perennis might be at risk of genetic swamping by its more widespread congener. We examined whether species were found under sympatric or parapatric settings with opportunity for hybridization (or gene exchange). Such knowledge is essential for implementing restoration management protocols, including the introduction of $C$. perennis into substitution sites where $C$. tenuis might be already present. Fourteen morphological characters and 11 soil variables were measured and visiting pollinator species were identified at the site where the two species co-occur. Our results show that the two species can be distinguished based on their morphological traits, show niche overlap based on edaphic properties, and share the same pollinator assemblage. In addition, no morphologically intermediate individuals could be detected, suggesting no hybridization, and that the two species may be reproductively isolated. We conclude that $C$. perennis conservation and restoration operations can be realized in substitution sites where $C$. tenuis may be present, with the need, however, to evaluate the potential effect of sharing a pollinator assemblage on reproductive success of both species.
\end{abstract}

Key words: edaphic endemism; ex situ conservation; geobotany; Katanga (Dem. Rep. Congo); metallophyte; plant-pollinator interactions; plant-soil relations; rarity.

MANy EDAPHICALLY ENDEMIC PLANTS, WITH RESTRICTED DISTRIBUTIONS AND SPECIFIC HABITAT requirements, are declining or have already gone extinct as a result of habitat destruction, fragmentation and degradation (e.g., Woodruff 2001, Jacobi et al. 2007). In addition to strongly decreasing population sizes, habitat fragmentation and degradation may increase the risk of hybridization between closely related species by bringing formerly allopatric species into sympatric settings (e.g., Rhymer \& Simberloff 1996, Lamont et al. 2003, Parsons \& Hermanutz 2006).

Hybridization, especially when occurring between a rare plant species and a more common congener, may lead to a genetic assimilation of the rare taxon by the common one through genetic swamping, leading to the loss of its unique characteristics, and ultimately to its extinction (e.g., Rieseberg 1991, Levin et al. 1996, Rhymer \& Simberloff 1996, Lamont et al. 2003, Parsons \& Hermanutz 2006). Reproductive-isolating mechanisms,

Received 20 December 2010; revision accepted 2 September 2011.

${ }^{7}$ Corresponding author; e-mail: michel-pierre.faucon@lasalle-beauvais.fr however, might prevent or limit between-species hybridization, such as differences in pollinator assemblages and flowering periods, incompatibility between pollen and stigmatic tissue, hybrid seed abortion, and reduced survival of the hybrid progeny (Rhymer \& Simberloff 1996, Arnold 1997, Campbell et al. 2002, Pascarella 2007). Hybridization between two taxa can be detected by several methods (Wilson 1992, Rieseberg \& Ellstrand 1993, McDade 1997, Parsons \& Hermanutz 2006). The use of molecular markers gives reliable results (Hegarty \& Hiscock 2005, Morgan-Richards et al. 2009), but their development may be time-consuming and costly. Because hybrids may consist of morphologically intermediate forms, morphometric trait analysis has also been largely used. This approach may be particularly useful when molecular markers are not available or difficult to develop (Soltis \& Gitzendanner 1999, Will \& Rubinoff 2004).

With increasing destruction of native habitat, in situ preservation for rare and endemic plant species is becoming difficult and other viable solutions for sustainable conservation need to be found. Ex situ conservation in botanical gardens (possibly 
combined with reintroduction upon habitat restoration), and plant relocation in other wild sites sharing similar ecological conditions are often proposed (Whiting et al. 2004). These conservation practices, however, might accidentally lead to hybridization between the rare, threatened species and more widespread congeners that may already be present in the potential introduction sites or in the garden, threatening the genetic integrity of the taxon to be preserved (Maunder et al. 2004a). This new coexistence might also lead to competition for space, resources or pollinators if they occupy similar ecological niches (Brown et al. 2002, Bachmann et al. 2005). This might compromise the longterm persistence of the introduced taxon, especially if it is not possible to create large populations. It is therefore essential, before starting any introduction or ex situ conservation planning, to properly evaluate the potential risk for hybridization between the endemic and the closely related species that may already occur in the substitution sites. Additionally, the risk for competition also needs to be assessed by characterizing their ecological niches. To our knowledge, only a few studies have investigated these particular issues despite the urgent need for preserving taxa by adequate ex situ conservation strategies (Parsons \& Hermanutz 2006, Kothera et al. 2007, Volis \& Blecher 2010, Zhang et al. 2010).

Endemic metallophytes are often directly threatened by surface mining activities exploiting economically important metals such as copper, cobalt or zinc (e.g., Bradshaw 2000, Whiting et al. 2004, Saad et al. 2011). Restoring the habitats after mining exploitation is often not possible and hence the main solution is to conduct ex situ conservation and/or to consider plant relocation in protected sites. Nevertheless, the degradation of metal outcrops by mining exploitation may also result the creation of new habitats metalliferous (e.g., Allen \& Sheppard 1971, Ginocchio et al. 2002, Batty 2005). Such sites can be recolonized by plant species adapted to open habitats and high metal toxicity, and therefore may also serve as substitution sites (e.g., Bradshaw 1983, Ash et al. 1994, Bizoux et al. 2008, Faucon et al. 2009). It might, however, bring formerly spatially isolated congeneric species to co-occur, increasing the risk of competition and hybridization.

In this article we investigated the relationships between two closely related metallophyte species belonging to the Linderniaceae (Rahmanzadeh et al. 2005), Crepidorbopalon perennis (P.A. Duvigneaud) Eb. Fisch. and C. tenuis (S. Moore) Eb. Fisch. (syn.: Lindernia damblonii P.A. Duvign.). Crepidorbopalon perennis is a narrow endemic pioneer species occurring on copper-rich soils, restricted to only one (formerly two) known site in the vicinity of Lubumbashi, Katanga, Democratic Republic of Congo (Duvigneaud \& Denaeyer-De Smet 1963, Brooks \& Malaisse 1985). Its restricted distribution, ability to grow on soils with extremely high copper and cobalt concentrations, and capacity to accumulate these metals (Brooks \& Malaisse 1985, Reeves \& Baker 2000) make $C$. perennis a taxon of high conservation value (Faucon et al. 2009, 2010). It is worth emphasizing that this species is critically endangered (Faucon et al. 2010) as more than 90 percent of its population has been destroyed, declining from about 100,000 individuals in 2006 to a few hundred in 2009 (Faucon 2009). Its persistence in situ appears to be compromised. Under these critical conditions, particular conservation measures are urgently needed, including the preservation of plants outside its original location. Unfortunately, ex situ transplantation attempts in botanical garden (Agronomy Faculty, Lubumbashi University) in 2006-2008 failed because C. perennis plants did not survive the drought of the dry season (Kizila 2009). Specific ecological conditions contributing to drought tolerance, such as micro-relief or symbiotic interaction with soil micro organisms may have been lacking. The only sustainable possibility appears to be creating new populations in substitution sites.

In the most suitable substitution sites, i.e., those sites with ecological conditions similar to the species' native site and offering some guarantee for long-term preservation, $C$. tenuis can be found. This species is rare, but has a much broader geographical range, sometimes occurring on non-metalliferous soils (Fischer 1999, Faucon et al. 2009). Duvigneaud and Denaeyer-De Smet (1963) suggested that the copper-specialist C. perennis might be a derivative of $C$. tenuis. So far, however, information is lacking in terms of their phylogenetic relationships. Given that Crepidorhopalon tenuis occurs in the only known C. perennis site (Duvigneaud \& Denaeyer-De Smet 1963) and that there have been high levels of disturbance because of industrial mining activities for at least more than a century, it is not known if these taxa ever coexisted before mining exploitation. This might have different consequences in terms of long-term preservation of C. temuis. Indeed, no study has investigated yet whether these species occur in sympatry and have overlapping ecological niches (e.g., similar soil requirements and pollinator assemblage), which might lead to inter-specific competition or if they coexist under parapatry, with distinct niches, implying no competition. Moreover, no information regarding their hybridization potential could be found. Before planning any ex situ conservation efforts it is essential to investigate how $C$. perennis and $C$. tenuis co-occur. Given the lack of available molecular markers, morphological traits were used for characterizing the two species. In this respect, several questions were addressed, as following: (1) based on the morphometric analysis of vegetative and floral traits can we detect morphologically intermediate hybrid forms between the two species? And, (2) do the ecological niches (based on edaphic conditions and pollinator assemblage) of the two species overlap? Our results will allow us to ascertain whether $C$. perennis may be at hybridization risk and/or in competition with its congener C. tenuis.

\section{METHODS}

STUDY TAXA—Crepidorbopalon perennis (Linderniaceae) is a small, cushion-forming, short-lived perennial herb, producing lilac-blue flowers. This narrow endemic occurs only in one (formerly two) known site (Mine de l'Etoile), where it colonizes disturbed mine deposits rich in copper. Crepidorhopalon perennis can flower the whole year, with a flowering peak in March-April. One plant of C. perennis produces on average 2227 seeds (ranging from 80 to 
$4400, N=20)$ that germinate at the beginning of the rainy season in November. The mean number of seeds per fruit is 30 (ranging from 12 to 61). The mean seed germination rate is 80 percent (M.-P. Faucon, unpubl. data).

Crepidorhopalon tenuis is a small annual herb, with lilac-blue flowers. This species is more common than $C$. perennis as it exists in 24 populations distributed in the Zambezian Regional Center of Endemism (southcentral Africa), of which 18 occur in Katanga (Faucon 2009). It grows on naturally copper-rich soils, but also on substrates (often mine debris) that have been disturbed and reworked by mining activities and on soil contaminated by atmospheric fallout from an ore-smelter foundry (in the Lubumbashi region). Crepidorhopalon tenuis has its ecological optimum in pioneer metalliferous habitats, especially on bare or recently disturbed substrates with high $\mathrm{Cu}$ contents, where perennial species have not yet established. It has also been occasionally found on non-metalliferous soil, and can therefore be considered as a pseudometallophyte (Fischer 1999, Leteinturier et al. 1999, Faucon et al. 2009). This species is not threatened and may currently be expanding in the recently created metalliferous habitats as a result of mining activities (Faucon et al. 2009). The plants flower from early March to late April, overlapping for 2 mo with C. perennis. A single plant can produce on average 1650 seeds (ranging from 40 to 2000) that germinate at the beginning of the rainy season in November. The seeds are dispersed from May to June. In permanently moist habitats, this species can germinate and complete its life cycle throughout the year. The mean number of seeds per fruit is 29 (ranging from 12 to 51). Mean germination rate is 70 percent. Based on flow cytometry, both species have the same ploidy level (Fig. S1). An in situ pollination (flower bagging) experiment — almost completely destroyed by mining activities - indicated that both species can produce seeds by selfing (M.-P. Faucon, unpubl. data).

STUDY SITE-The study site was the Mine de l'Etoile (locally known as Kalukuluku), which is situated $\sim 10 \mathrm{~km}$ northeast of Lubumbashi (Province of Katanga, Democratic Republic of Congo; $11^{\circ} 38^{\prime} \mathrm{S} ; 27^{\circ} 35^{\prime} \mathrm{E}$, $1277 \mathrm{~m}$ asl). This site supports a diverse copper flora (about 150 vascular plant taxa) from Katanga (Duvigneaud \& Denaeyer-De Smet 1963, Malaisse \& Grégoire 1978). It covers more than $2 \mathrm{~km}^{2}$ and offers a broad spectrum of ecological conditions, from recently disturbed mine debris to ancient steppic savanna. Recent revival of mining activity, however, has considerably altered the site and the endemic flora of the site is now endangered. Five sites where C. tenuis occurs, located in Katanga province (Dem. Rep. of Congo) were also studied for the assessment of the soil/ecological niche characteristics of this taxon and investigating their potential as substitution sites for C. perennis.

MORPHOLOGICAL AND EDAPHIC VARIATION-To examine ecological and morphological variation in $C$. perennis and $C$. tenuis, several traits were measured in the field on fresh plant material for 20 individuals of the population of each species in the one sympatric location at the Mine de l'Etoile. Individuals were randomly sam- pled in April 2008 along a transect length of $200 \mathrm{~m}$. Identification of $C$. perennis and $C$. tenuis was based on the taxonomic treatment for Crepidorhopalon (Fischer 1999). For each individual, 14 morphological characters were measured on three flowers and two leaves (Fig. 1): cauline leaf length ( $\mathrm{L} \downarrow$ and width $(\mathrm{L} w)$, bract length (B $\zeta$ ) and width (B w), corolla upper lip length (UL $l$ ) and width (UL $w$ ), lower lip 1 length (LL1 $l$ ) and width (LL1 $w)$ ), lower lip 2 length (LL2 $)$ and width (LL2 w), lower lip 3 length (LL3 I) and width (LL3 w), and corolla tube diameter (CT d) and length (CT $)$. These variables were used to calculate the following variables expressing plant (leaf, bract and flower) shape: L //L w, B // $\mathrm{B} w$, UL $/ / \mathrm{UL} w$, LL1 l/LL1 $w$, LL2 l/LL2 $w$, LL3 //LL3 $w$, and CT $/ / \mathrm{CT} d$. For the 21 variables, mean values per individual were calculated.

To confirm that the observed patterns between species were constant when considering other $C$. tenuis populations, morphological measures (with mean values per individual) were made on three flowers and two cauline leaves from dried herbarium specimens (from BR and BRLU herbaria), for 20 individuals of C. perennis from the Mine de l'Etoile and from 40 individuals of C. tenuis from 16 metallicolous populations in Katanga. Thirteen variables that could be measured on dry material were obtained:

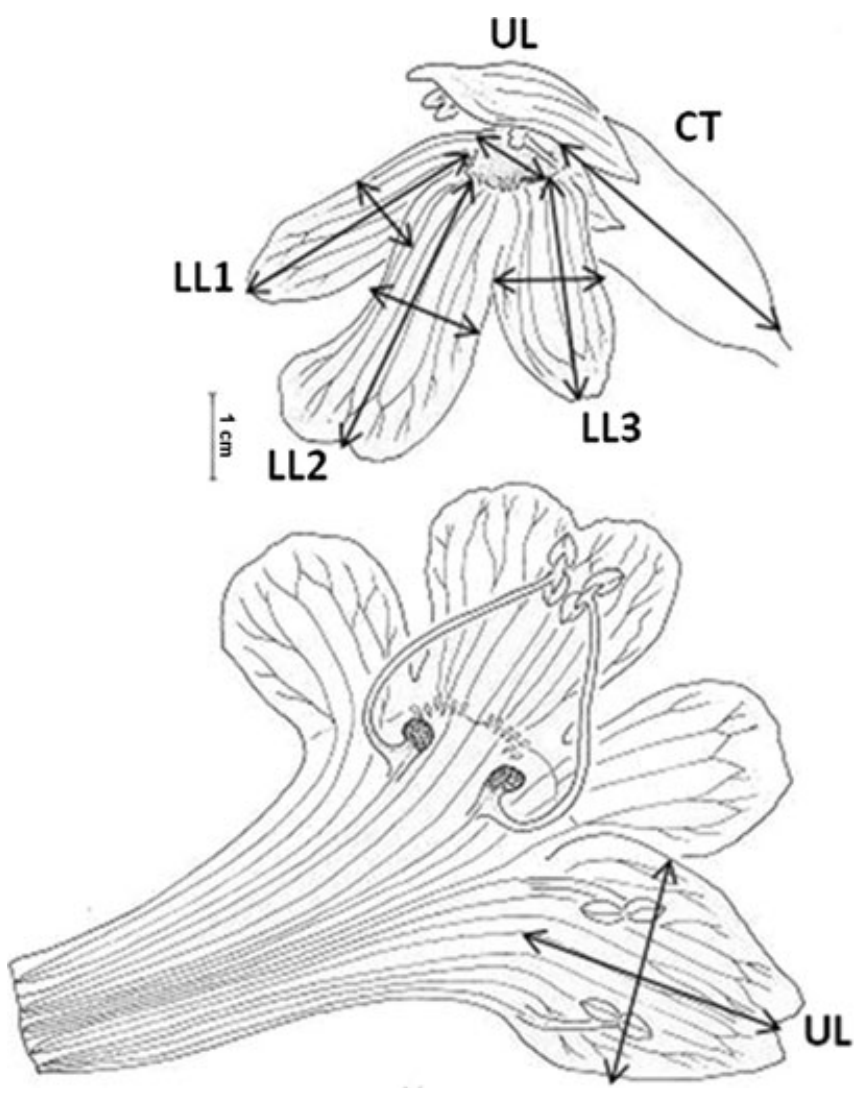

FIGURE 1. Floral characters (maximal lengths and widths) measured in Crepidorhopalon perennis and C. tenuis (from Fischer 1999). CT: corolla tube; UL: upper lip of corolla; LL: lower lip of corolla; LL1: sub lower lip right; LL2: sub lower lip median; LL3: sub lower lip left. 
cauline leaf length ( $\mathrm{L} l$ ) and width $(\mathrm{L} w)$, bract length (B I) and width (B w), corolla tube length (CT $\eta$ ), calyx length (Caly $\emptyset$ and width (Caly $w)$, capsule length (Caps $h$ and width (Caps $w)$, and variables expressing shape (L $l / \mathrm{L} w, \mathrm{~B} / / \mathrm{B} w$, Caly $/ /$ Caly $w$, and Caps $/ /$ Caps $w)$.

To characterize the chemical and physical soil conditions near $C$. perennis and C. tenuis plants, 20 soil samples of $100 \mathrm{~g}$ each were collected from each site and species from the rhizosphere of each individual $(0-10 \mathrm{~cm})$ at Mine de l'Etoile and five other sites where $C$. tenuis occurs. All soil samples were air-dried and sieved using a 2-mm stainless steel sieve. The $\mathrm{pH}$ (water) was measured with a glass electrode (VWR symphony SP70C). Organic matter content was measured by loss on ignition at $550^{\circ} \mathrm{C}$ during $12 \mathrm{~h}$. Mineral elements were extracted with ammonium acetate-EDTA (1M, pH 4.65) for $30 \mathrm{~min}$. (5 g dry soil in $50 \mathrm{ml}$ ) (Cottenie et al. 1982). The supernatant was then filtered and analyzed by inductively coupled plasma-optical emission spectrometry (ICP-OES) (Varian Vista MPX, Mugrave, Australia) for the characterization of the extractable fractions of $\mathrm{Ca}, \mathrm{Mg}, \mathrm{K}, \mathrm{P}$, $\mathrm{Cu}, \mathrm{Co}, \mathrm{Mn}, \mathrm{Fe}$ and $\mathrm{Zn}$.

Poldinator sampling-To investigate whether $C$. perennis and $C$. tenuis might compete for pollinators, we characterized the pollinator assemblage during peak flowering (April) for both species. Twenty plots of $0.5 \times 0.5 \mathrm{~m}$ showing 100 percent flowering plant cover were randomly located in the area of the site where both species occurred. Ten plots corresponded to monospecific patches of $C$. perennis and ten plots to $C$. tenuis. The observations were made from 0700 to $1800 \mathrm{~h}$, and were repeated the next day. The observations in monospecific plots of $C$. perennis and C. tenuis were made one plot after the other by alternating the species. The order of plot observations was the same for the $2 \mathrm{~d}$. Each day, in each plot, all insects visiting flowers of $C$. perennis and of $C$. tenuis were counted for a period of $20 \mathrm{~min}$. An insect was considered as a visitor when it landed on at least one open flower, for at least $1 \mathrm{~s}$. Captured insects were conserved in 5 percent ethanol and identified subsequently (S. Patiny, University of Liège, Belgium). Most species could not be identified to the species level, but in this case they were well individualized as separate taxa based on their morphology. Mean values of the number of visiting insects were calculated for each plot and each insect taxon as a mean of the observations made for the $2 \mathrm{~d}$.

DATA ANALYSIS-To distinguish between $C$. perennis from C. tenuis with respect to leaf and floral morphology, one-way ANOVAs testing for significant differences in morphological traits between species were performed using STATISTICA 8 (Statsoft 2008, Tulsa, OK, U.S.A.). To summarize the patterns of interrelationships of morphological characters, a Principal Component Analysis (PCA) was performed using CANOCO 4.5 (ter Braak \& Smilauer 2002). The Bonferroni correction method for multiple comparisons (Rice 1989) was applied when multiple tests were involved.

The potential for hybridization between C. perennis and C. tenuis was evaluated using the methodology of Parsons and Hermanutz (2006), which is based on an analysis of floral morphological variation. To identify morphologically intermediate individuals, relative distances were computed between all pairs of individuals of $C$. perennis and $C$. tenuis based on ten floral morphological traits (the same floral morphological traits as for ACP). A cluster analysis was performed on the matrix of relative Euclidean distances using the Ward's method (Ward 1963). Differences in floral morphological traits between the two groups identified by the clustering method, corresponding to the two species were tested using the multi-response permutation procedure (MRPP), a non-parametric method (Biodini et al. 1988). Cluster analysis and MRPP were performed using PC-ORD v. 4.26 (McCune \& Mefford 1999).

The range of edaphic variation of each species was investigated by performing PCA on 11 chemical $(\mathrm{pH}$, organic matter content, $\mathrm{Ca}, \mathrm{Mg}, \mathrm{K}, \mathrm{P}, \mathrm{Cu}, \mathrm{Co}, \mathrm{Mn}, \mathrm{Fe}$ and $\mathrm{Zn}$ ) and one physical (\% stones) soil properties measured in the vicinity of the 40 C. perennis and C. tenuis individuals. Because they varied in measurement units and ranges, all morphological and edaphic variables were standardized (ter Braak \& Smilauer 2002). All variables were normally distributed.

The differences in number of visited flowers per plot between $C$. perennis and $C$. tenuis were investigated for each insect taxon using non-parametric Kruskal-Wallis tests (data not normally-distributed) with the mean of number of visited flowers per plot as dependent variable and species as grouping variable. Bonferroni corrections for multiple tests were used for assessing significance.

\section{RESULTS}

MorphologicAl VARIATION AND DETECTION OF HYBRIDS-The one-way ANOVAs revealed that the two congeneric species $C$. perennis and $C$. tenuis showed significant differences $(P<0.0025$ after Bonferroni correction) in morphological traits (Table 1): C. perennis had longer but narrower leaves, longer bracts, and longer lower corolla lips 1 and 2 than C. tenuis. Axes 1 and 2 of the PCA explained 50 percent of the total variation in the 21 morphological variables (Fig. S2). The variables that best correlated with axis 1 (PC1) were: leaf length: width ratio (L //L $w$; coefficient of correlation $r=-0.67$ ), length of the three lower lips (LL1 $l$, LL2 $l$ and LL3 $l ; r=-0.89,-0.78$ and -0.86 , respectively), bract length $(r=-0.67)$, and leaf length $(r=0.56)$. Those that best correlated with axis 2 (PC2) were the width of the three lower lips (LL1 $w$, LL2 $w$ and LL3 $w ; r=-0.87,-0.84$ and -0.87 , respectively) and leaf length $(r=0.46)$. Crepidorbopalon perennis plants formed a distinct group with negative values on PC1 (Fig. S2), whereas C. tenuis plants had positive values on PC1. The PCA showed high intra-specific morphological variation in both species. The range of variation in $C$. perennis was similar to the range observed in C. tenuis (Fig. S2). The cluster analysis based on floral traits indicated that the two species were separated into two groups, belonging to two separated clusters (Fig. 2). These groups were significantly different when tested by MRPP $(A=0.207, P<0.001)$. PCA using 13 morphological variables measured on dried herbarium material of $C$. perennis 
TABLE 1. Morphological characters (mean values, in $\mathrm{mm}$ ) for C. perennis and C. tenuis species, and one-way ANOVA tests (F).

\begin{tabular}{|c|c|c|c|}
\hline Morphological Characters & $\begin{array}{l}\text { C. perennis } \\
\text { Mean (SD) }\end{array}$ & $\begin{array}{c}\text { C. tenuis } \\
\text { Mean (SD) }\end{array}$ & $F_{1,39}$ \\
\hline Leaf length (L $)$ & $11.85(2.91)$ & $9.28(2.79)$ & $8.11^{*}$ \\
\hline Leaf width $(\mathrm{L} w)$ & $1.75(0.57)$ & $3.50(1.41)$ & $26.42^{*}$ \\
\hline $\mathrm{L} l / \mathrm{L} w$ & $7.10(1.73)$ & $3.13(1.96)$ & $46.22^{*}$ \\
\hline Bract length (B D) & $6.53(1.45)$ & $3.54(1.45)$ & $42.73^{*}$ \\
\hline Bract width (B w) & $1.03(0.36)$ & $0.74(0.38)$ & $6.02 \mathrm{~ns}$ \\
\hline $\mathrm{B} l / \mathrm{B} w$ & $6.74(1.71)$ & $5.21(1.98)$ & $6.81 \mathrm{~ns}$ \\
\hline Upper lip length (UL I) & $3.29(0.27)$ & $3.29(0.31)$ & $1.03 \mathrm{~ns}$ \\
\hline Upper lip width (UL $w)$ & $2.86(0.24)$ & $2.70(0.25)$ & $4.26 \mathrm{~ns}$ \\
\hline $\mathrm{UL} l / \mathrm{UL} w$ & $1.15(0.09)$ & $1.22(0.12)$ & $4.24 \mathrm{~ns}$ \\
\hline Lower lip 1 length (LL1 $)$ & $3.36(0.33)$ & $3.03(0.40)$ & $7.92^{*}$ \\
\hline Lower lip 1 width (LL1 w) & $2.18(0.21)$ & $2.22(0.26)$ & $0.21 \mathrm{~ns}$ \\
\hline LL1 l/LL1 $w$ & $1.54(0.11)$ & $1.37(0.13)$ & $19.03^{*}$ \\
\hline Lower lip 2 length (LL2 l) & $3.19(0.31)$ & $3.03(0.41)$ & $2.02 \mathrm{~ns}$ \\
\hline Lower lip 2 width (LL2 w) & $2.01(0.19)$ & $2.10(0.37)$ & $1.07 \mathrm{~ns}$ \\
\hline LL2 l/LL2 $w$ & $1.59(0.12)$ & $1.45(0.14)$ & $11.11^{*}$ \\
\hline Lower lip 3 length (LL3 I) & $3.21(0.25)$ & $2.90(0.33)$ & $11.71^{*}$ \\
\hline Lower lip 3 width (LL3 w) & $2.09(0.18)$ & $2.11(0.21)$ & $0.13 \mathrm{~ns}$ \\
\hline LL3 $/ /$ LL3 $w$ & $1.54(0.09)$ & $1.38(0.14)$ & $17.40^{*}$ \\
\hline Corolla tube diameter (CT $d$ ) & $2.59(0.24)$ & $2.60(0.22)$ & $0.01 \mathrm{~ns}$ \\
\hline Corolla tube length (CT $)$ & $5.24(0.21)$ & $5.16(0.35)$ & $0.80 \mathrm{~ns}$ \\
\hline $\mathrm{CT} l / \mathrm{CT} d$ & $2.03(0.16)$ & $1.99(0.18)$ & $0.60 \mathrm{~ns}$ \\
\hline
\end{tabular}

$* P<0.0025$ after Bonferroni correction, ns $=$ not significant.

from the Mine de l'Etoile and of C. tenuis from 16 metallicolous populations showed the same pattern of species clustering into two distinct groups (Fig. S3).

ECOLOGICAL NICHE VARIATION (SOIL AND POLLINATOR assemblage)-Axes 1 and 2 of the PCA on 11 chemical $(\mathrm{pH}$, organic matter content, $\mathrm{Ca}, \mathrm{Mg}, \mathrm{K}, \mathrm{P}, \mathrm{Cu}, \mathrm{Co}, \mathrm{Mn}, \mathrm{Fe}$ and $\mathrm{Zn}$ ) and one physical (percentage of stones) soil properties explained
48 percent of the total variation (Fig. S4). The variables that best correlated with axis 1 (PC1) were $\mathrm{Co}, \mathrm{Cu}, \mathrm{Mn}, \mathrm{pH}$ and $\mathrm{P}$ (positive correlation, $r \geq 0.70$ ), and with axis 2 (PC2) were $\mathrm{K}$, Ca, $\mathrm{Mg}$ and organic matter (positive correlation, $r \geq 0.65$ ). The individuals of $C$. perennis showed higher scores on PC1 (i.e., higher $\mathrm{Cu}$ and $\mathrm{Co}$ contents) than $C$. tenuis. There was niche overlap (about $80 \%$ ) between the two species with respect to soil chemical conditions. Crepidorhopalon perennis showed an ecological range as broad as C. tenuis (Fig. S4).

Ten different insect species were observed visiting $C$. perennis and $C$. tenuis, which belong to eight taxonomic families and three orders (Table 2). The most heavily represented order and family was Hymenoptera: Sphecidae with three species (Table 2). Ammophila appeared to be the most abundant genus observed on C. perennis and C. tenuis flowers, with an average range of 0.12 to 0.71 visits per plot per $20 \mathrm{~min}$. Three other species of Hymenoptera were frequent (up to 8 visits per plot per $20 \mathrm{~min}$ ): Amegilla sp. (Apidae), Bembix sp. (Crabronidae) and Lasioglossum sp. (Halictidae). Crepidorhopalon perennis and $C$. tenuis were visited by the ten same species. No significant difference in the number of visits by insects was found between the two species (Kruskal-Wallis test: $\mathrm{H}<1, P>0.05)$.

\section{DISCUSSION}

CREPIDORHOPALON PERENNIS AND C. TENUIS, TWO Distinct MORPHOLOGICAL ENTITIES-The traits used in the literature to distinguish $C$. perennis and $C$. tenuis are (1) the contrasting life cycle (perennial vs. annual, respectively) and; (2) the number of basal leaves, which is higher in C. perennis (Fischer 1999). Although a close morphological resemblance was emphasized by several studies (Duvigneaud \& Denaeyer-De Smet 1963, Brooks \& Malaisse 1985), none were based on quantitative trait measurements. Our results show, for the first time, that although the two species have very similar appearance, they can be easily defined based on a combination of morphological traits. Significant morphological differences exist between the two species, especially in leaf length and width, in bract length and in the length of the lower corolla

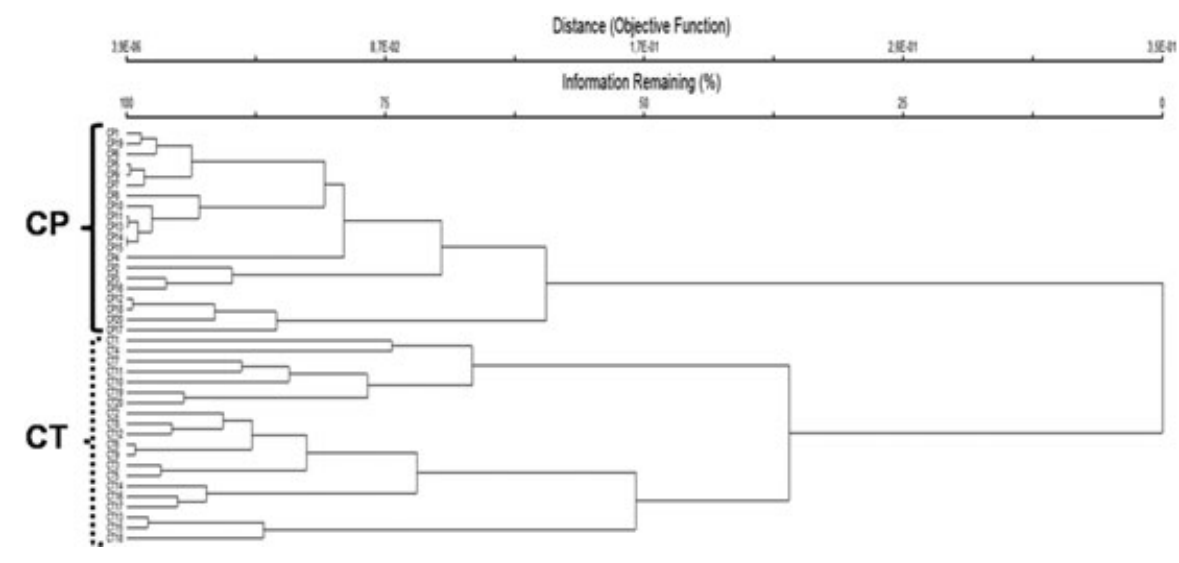

FIGURE 2. Ward's dendrogram of the cluster analysis on floral characters for 20 individuals of Crepidorhopalon perennis (CP) and of C. tenuis (CT). 
TABLE 2. Number (N) of visits per 20 min (mean value with SD in the brackets) for each insect taxon in 10 plots of $\mathrm{C}$. perennis and $\mathrm{C}$. tenuis. KruskatWallis tests were not significant $(\mathrm{P}>0.05)$.

\begin{tabular}{|c|c|c|c|c|}
\hline Order & Family & Taxon & $\begin{array}{c}N \text { visits }(\mathrm{SD}) \\
\text { C. perennis }\end{array}$ & $\begin{array}{c}N \text { visits (SD) } \\
\text { C. tenuis }\end{array}$ \\
\hline Hymenoptera & Sphecidae & $\begin{array}{l}\text { Ammophila } \\
\text { species } 1\end{array}$ & $0.71(1.23)$ & $0.41(0.85)$ \\
\hline Hymenoptera & Sphecidae & $\begin{array}{l}\text { Ammophila } \\
\text { species } 2\end{array}$ & $0.12(0.46)$ & $0.25(0.55)$ \\
\hline Hymenoptera & Formicidae & species 3 & $0.05(0.21)$ & $0.12(0.86)$ \\
\hline Hymenoptera & Apidae & Amegilla sp. & $0.55(1.33)$ & $0.27(0.61)$ \\
\hline Hymenoptera & Crabonidae & Bembix sp. & $0.42(1.82)$ & $0.23(0.55)$ \\
\hline Hymenoptera & Sphecidae & $\begin{array}{r}\text { Podalonia } \\
\text { sheffieldi }\end{array}$ & $0.05(0.23)$ & $0.04(0.23)$ \\
\hline Hymenoptera & Halictidae & Lasioglossum sp. & $0.35(1.37)$ & $0.21(0.73)$ \\
\hline Hymenoptera & Crabonidae & Tachysphex sp. & $0.05(0.23)$ & $0.05(0.32)$ \\
\hline Lepidoptera & Nymphalidae & $\begin{array}{l}\text { Acraea } \\
\text { psendolycia }\end{array}$ & $0.05(0.25)$ & $0.05(0.29)$ \\
\hline Diptera & Syrphidae & species 4 & $0.05(0.21)$ & $0.45(1.64)$ \\
\hline
\end{tabular}

lips. Some of these may have an adaptive significance: for instance, leaves are much wider and therefore their area is about three times higher for $C$. tenuis (mean value $=3.2 \mathrm{~cm}^{2}$ ) than for C. perennis (mean value $=1.9 \mathrm{~cm}^{2}$ ). This difference might be explained by their annual or perennial life history traits and their respective growth season. Indeed, because of their short life cycle, higher leaf area can be expected in annual plant species compared with perennial congeners (Garnier 1992). The narrower leaves of C. perennis may also represent an adaptation to drought (Turner 1986), as C. perennis grows during both wet and dry seasons, whereas $C$. tenuis plant growth takes place mainly during the wet season. Besides, C. perennis has a longer flowering period than C. tenuis, and may therefore be visited by other pollinator guilds. Difference of pollinator guilds might have contributed to fix the differences in the corolla shape and size (Fenster et al. 2004).

CoHABitation OR HYBridizATIOn?-The two species appear to grow in sympatry rather than in parapatry: there is a niche overlap between the two species, and individuals of both populations may be spatially intermixed. Crepidorhopalon perennis, however, occurs mostly in the most contaminated and alkaline soils (higher concentrations of $\mathrm{Co}, \mathrm{Cu}$ and $\mathrm{pH}$ ) and $C$. tenuis in more fertile soils (higher contents of $\mathrm{Ca}, \mathrm{K}, \mathrm{Mg}$ and organic matter), suggesting that there might be an ecological segregation at a very fine scale. Moreover, from our study it appears that they share the same pollinator assemblage, suggesting that pollen transfer might occur between the two species. This could potentially result in pollen waste and clogging by heterospecific pollen for the rarer species (Kwak et al. 1998, Wilcock \& Neiland 2002). These findings, combined with a two-month overlapping flowering period, might favor interspecific crossings and hybrid appearance. Yet no evidence of hybridization was found between $C$. perennis and $C$. tenuis, as no morphologically interme- diate individuals could be identified, even under conditions suited for hybridization. Therefore, our failure to detect hybrids suggests that the two species might not be inter-fertile, resulting from prezygotic reproductive isolating mechanisms (Levin 1971, Pascarella 2007), perhaps through pollen-stigma incompatibility. Differences in floral features, such as corolla shape or size, may differentially attract pollinators and also contribute to reproductive isolation (e.g., Gardner \& Macnair 1999, Rajakaruna 2004). Despite the longer flower lips found for C. perennis, however, no difference in pollinator assemblage was observed between the two species.

Postzygotic mechanisms, such as hybrid seed abortion, seedling inviability and adult sterility, may also lead to reproductive isolation (Ramsey et al. 2003, Taylor et al. 2009). Hybrid plant fitness may be reduced in either parental habitat compared with the two species (Van Rossum et al. 1996, Rieseberg \& Carney 1998, Arnold et al. 2008). The drought of the dry season (MayOctober) in Katanga might represent a strong selection pressure against hybrids between $C$. perennis and $C$. tenuis, as one of the parental species (C. tenuis) mainly grows during the wet season and has wider leaves, less adapted to drought. Hybrids, however, might not always be morphologically intermediate (Abbott \& Low 1996, Rieseberg \& Carney 1998). They might also be diluted in the many descendants of $C$. perennis that may be produced outside the flowering of $C$. tenuis (May-February). Our results certainly deserve further investigation for confirmation, e.g., by crossing experiments between the two species, by testing withinand between-species pollen-stigma compatibility and using molecular markers for hybrid detection.

IMPLICATIONS FOR CONSERVATION MANAGEMENT-The endemic C. perennis is critically endangered because the area occupied by its population has been considerably reduced by intensive mining. From 100,000 individuals recorded in 2006 only a few hundred still exist nowadays (Faucon 2009). This is a critical situation that requires urgent conservation measures and may justify population translocation (IUCN World Conservation Union 2002, Guerrant et al. 2004, Maunder et al. 2004b). The ex situ conservation efforts consisting in keeping a living collection of plants in the botanical garden at Lubumbashi University failed, likely because of the difficulty for recreating suitable ecological conditions for the taxon, e.g., micro-relief and top soil conditions (Kizila 2009). The introduction of a population to a substitution site seems the only solution for the conservation of this taxon. Such management of a threatened species requires precise species delineation, including studies of its biology and restoration potential. Our data indicate that $C$. perennis conservation program could be carried out without necessarily taking the presence of $C$. tenuis into account. The lack of hybridization with its congener, $C$. tenuis, allows the introduction of $C$. perennis to ecologically suitable sites, where $C$. tenuis often occurs. Our soil data (Fig. S4) suggest that Niamumenda and Kalabi populations might be good candidates. Whether the sharing of pollinators contributes to gene exchange between the two species or result in competition for pollinators, however, certainly requires further investigation. This is essential for properly 
assessing the minimal population sizes needed for establishment. The apparently wide ecological amplitude of C. perennis, and its ability to colonize anthropogenic copper-rich habitats, indicates that C. perennis could succeed in other metalliferous habitats outside its native site.

Perspectives-To propose an adequate ex situ conservation program further studies may be pursued. Firstly, it is necessary to confirm the absence of a hybridization risk between the two species and to know more about their reproductive systems. Crossing experiments and the study of the genetic diversity and structure using molecular markers may allow the estimation of the selfing and outcrossing rates, assessing pollen compatibility between species and detecting if gene exchange exists between species by identifying hybrids. Secondly, before starting any largescale introduction of plants in substitution sites, it is essential to confirm that this species is able to grow outside its native site, by preliminary transplantation experiments, using seeds and/or plants. Finally, it is necessary to identify the key factors for the long-term persistence of the newly created populations, e.g., by long-term studying the dynamics of the population demographic, and by investigating seed dispersal ability of species and pollination processes.

\section{ACKNOWLEDGMENTS}

The Belgian Fund for Scientific Research (FNRS) is acknowledged for financial support to MPF, who was a research fellow of the Fonds pour la Recherche dans l'Industrie et l'Agriculture (FRIA, Belgium). We are grateful to Sébastien Patiny from Unit Functional and Evolutionary Entomology (Université de Liège, Belgium) for insect determination and to Mylor Shutcha and Pacific Kizila from the Agronomy Faculty (Lubumbashi University, DRCongo) for technical assistance and to Petru Jitaru from LaSalle Beauvais for revision of English text. We are also grateful to the NGO Biodiversité au Katanga (BAK) for their beneficial collaboration in the global project to conserve biodiversity in Katanga. This work was a part of the Projet Inter-universitaire Cible (REMEDLU Project) funded by the Coopération Universitaire au Développement (CUD, Belgium).

\section{SUPPORTING INFORMATION}

Additional Supporting Information may be found in the online version of this article:

FIGURE S1. Flow cytometry data of individuals of Crepidorhopalon perennis and C. tenuis from Mine de l'Etoile.

FIGURE S2. Principal components analysis biplot of 21 morphological variables for 20 individuals of Crepidorhopalon perennis and of C. tenuis.

FIGURE S3. Principal components analysis biplot of 15 morphological variables for 20 individuals of Crepidorhopalon perennis and for 40 individuals of $C$. tenuis from 16 metalliferous sites in Katanga.
FIGURE S4. Principal components analysis biplot of 11 edaphic variables measured for Crepidorhopalon perennis population and for six C. tenuis populations.

Please note: Wiley-Blackwell are not responsible for the content or functionality of any supporting materials supplied by the authors. Any queries (other than missing material) should be directed to the corresponding author for the article.

\section{LITERATURE CITED}

Аввотт, R. J., AND A. J. Low. 1996. A review of hybridization and evolution in British Senecio. In D. J. N. Hind, and H. J. Beentje (Eds.). Compositae, Systematics, pp. 679-689. Proceedings of the International Compositae Conference, Kew. Royal Botanic Gardens, Kew, UK.

Allen, W. R., And P. M. Sheppard. 1971. Copper tolerance in some Californian populations of the monkey flower, Mimulus guttatus. Proc. R. Soc. B, 177: 177-196.

Arnold, M. L. 1997. Natural Hybridization and Evolution. Oxford University Press, New York.

Arnold, M. L., R. S. Cornman, and N. H. Martin. 2008. Hybridization, hybrid fitness and the evolution or adaptations. Plant Biosyst, 142: 166-171.

Ash, H. J., R. P. Gemmell, and A. D. Bradshaw. 1994. The introduction of native plant species on industrial waste heaps: A test of immigration and other factors affecting primary succession. J. Appl. Ecol., 31: 74-84.

Bachmann, U., I. Hensen, And M. Partsch. 2005. Is Campanula glomerata threatened by competition of expanding grasses? Plant Ecol., 180: 257-65.

BatTy, L. C. 2005. The potential importance of mine sites for biodiversity. Mine Water Environ., 24: 101-103.

Biodini, M. E., P. W. Mielke JR, And K. J. Berry. 1988. Data-dependent permutation techniques for the analysis of ecological data. Vegetatio, 75: 161-168.

Bizoux, J. P., K. Daïnou, O. Raspé, S. Lutts, and G. Mahy. 2008. Fitness and genetic variation of Viola calaminaria, an endemic metallophyte: Implications of population structure and history. Plant Biol., 10: 68493.

Bradshaw, A. D. 1983. The reconstruction of ecosystems. J. Appl. Ecol., 20: $1-17$.

Bradshaw, A. D. 2000. The use of natural processes in reclamationadvantages and difficulties. Lands. Urb. Plan., 51: 89-100.

Brooks, R. R., and F. Malaisse. 1985. The Heavy Metal-Tolerant Flora of South-central Africa - A Multidisciplinary Approach. Balkema, Rotterdam, The Netherlands.

Brown, B. J., R. J. Mitchell, and S. A. Graham. 2002. Competition for pollination between an invasive species (purple loosestrife) and a native congener. Ecology, 83: 2328-2336.

Campbell, D. R., N. M. Waser, and G. T. Pederson. 2002. Predicting patterns of mating and potential hybridization from pollinator behavior. Am. Nat., 159: 438-450.

Chari, J., And P. Wilson. 2001. Factors limiting hybridization between Penstemon spectabilis and Penstemon centranthifolius. Can. J. Bot., 79: 1439-1448.

Cottenie, A., M. Verloo, L. Kiekens, G. R. Velghe, and R. Camerlynck. 1982. Chemical Analysis of Plants and Soils. Instituut tot Aanmoediging van het Wetenschappelijk Onderzoek in Nijverheid en Landbouw, Brussels, Belgium.

Duvigneaud, P., and S. Denaeyer-De Smet. 1963. Cuivre et végétation au Katanga. Bulletin de la Société Royale de Botanique de Belgique, 96: 92-231.

Faucon, M.-P. 2009. Ecologie et biologie de la conservation des métallophytes. Le cas de Crepidorhopalon perennis et C. tenuis (Scrophulariaceae) 
des sols cupro-cobaltifères du Katanga. PhD Dissertation. Université Libre de Bruxelles, Belgium.

Faucon, M.-P., G. Colinet, G. Mahy, M. Ngongo Luhembwe, N. Verbruggen, and P. Meerts. 2009. Soil influence on $\mathrm{Cu}$ and $\mathrm{Co}$ uptake and plant size in the cuprophytes Crepidorhopalon perennis and C. tenuis (Scrophulariaceae) in SC Africa. Plant Soil, 317: 201-212.

Faucon, M.-P., A. Meersseman, M. Shutcha, G. Mahy, F. Malaisse, M. Ngongo Luhembiwe, and P. Meerts. 2010. Copper endemism in the Congolese flora: A database of copper affinity and conservation value of cuprophytes. Plant Ecol. Evol., 143: 5-20.

Faucon, M.-P., I. Parmentier, G. Colinet, G. Mahy, M. Ngongo Luhembiwe, AND P. MeErTs. 2011. May rare metallophytes benefit from disturbed soils following mining activity? The case of the Crepidorhopalon tenuis in Katanga (DRCongo). Restor. Ecol., 19: 333-343.

Fenster, C. B., W., S. Armbruster, P. Wilson, M., R. Dudash, J., and D. Thomson. 2004. Pollination syndromes and floral specialization. Ann. Rev. Ecol. Evol. Syst., 35: 375-403.

Fischer, E. 1999. Scrophulariaceae (première partie). In P. Bamps (Ed.). Flore d'Afrique Centrale (Congo Kinshasa-Rwanda-Burundi), pp. 1-217. National Botanic Garden of Belgium, Meise, Belgium.

GarNIER, E. 1992. Growth analysis of congeneric annual and perennial grass species. J. Ecol., 80: 665-675.

Gardner, M., And M. R. Macnair. 1999. The Evolution of Edaphic Endemics. In D. J. Howard, and S. H. Berlocher (Eds.). Endless Forms: Species and Speciation, pp. 157-171. Oxford University Press, Oxford, UK.

Ginocchio, R., I. Toro, And D. Schnepf. 2002. Copper tolerance in populations of Mimulus luteus var. variegatus exposed and non exposed to copper pollution. Geochem. Explor. Environ. Anal., 2: 151-156.

Guerrant, E. O., K. Havens, And M. Maunder. 2004. Ex Situ Plant Conservation: Supporting Species Survival in the Wild. Island Press, Washington, DC.

Hegarty, M. J., and S. J. Hiscock. 2005. Hybrid speciation in plants: New insights from molecular studies. New Phytol., 165: 411-423.

IUCN World Conservation Union. 2002. IUCN technical guidelines on the management of ex situ populations for conservation. The 14th Meeting of the Programme Committee of Council, Gland, Switzerland. Available at: http://www.iucn.org/ (accessed 10 December 2002).

Jacobi, C. M., F. F. Carmo, R. C. Vincent, and J. R. Stehmann. 2007. Plant communities on ironstone outcrops-a diverse and endangered Brazilian ecosystem. Biodivers. Conserv., 16: 2185-2200.

KiziLA, P. 2009. Conservation ex situ de deux métallophytes en danger critique d'extinction, Crepidorbopalon perennis et Crotalaria peschiana. Engineer Thesis, Université de Lubumbashi, DRCongo.

Kothera, L., S. M. Ward, and S. E. Carney. 2007. Assessing the threat from hybridization to the rare endemic Physaria bellii Mulligan (Brassicaceae). Biol. Conserv., 140: 110-118.

Kwak, M. M., O. Velterop, and J. van Andel. 1998. Pollen and gene flow in fragmented habitats. Appl. Veg. Sci., 1: 37-54.

Lamont, B. B., T. He, N. J. Enright, S. L. Krauss, and B. P. Miller. 2003. Anthropogenic disturbance promotes hybridization between Banksia species by altering their biology. J. Evol. Biol., 16: 551-557.

Leteinturier, B., A. J. M. Baker, and F. Malaisse. 1999. Early stages of natural revegetation of metalliferous mine workings in South Central Africa: A preliminary survey. Biotechnologie Agronomie Société Environnement, 3: 28-41.

LEvin, D. A. 1971. The origin of reproductive isolating mechanisms in flowering plants. Taxon, 20: 91-113.

Levin, D. A., J. Franciso-Ortega, and R. K. Jansen. 1996. Hybridization and the extinction of rare plant species. Conserv. Biol., 10: 10-16.

Malaisse, F., And J. Grégoire. 1978. Contribution à la phytogéochimie de la Mine de l'Étoile (Shaba, Zaïre). Bulletin de la Société Royale de Botanique de Belgique, 111: 252-260.

Maunder, M., C. Hughes, J. A. Hawkins, and A. Culham. 2004a. Hybridization in ex situ plant collections: Conservation concerns, liabilities, and opportunities. In E. O. Guerrant, K. Havens, and M. Maunder (Eds.). Ex Situ Plant Conservation: Supporting Species Survival in the Wild, pp. 325-364. Island Press, Washington, DC.

Maunder, M., E. O. Guerrant, K. Havens, and K. W. Dixon. 2004b. Realizing the full potential of ex situ contributions to global plant conservation. In E. O. Guerrant, K. Havens, and M. Maunder (Eds.). Ex Situ Plant Conservation: Supporting Species Survival in the Wild, pp. 389-418. Island Press, Washington, DC.

McCune, B., And M. J. Mefford. 1999. PC-ORD. Multivariate Analysis of Ecological Data, version 4.2.1. MjM Software, Gleneden Beach, Oregon.

MCDADE, L. A. 1997. Hybrids and phylogenetic systematics III. Comparison with distance methods. Syst. Bot., 22: 669-683.

Morgan-Richards, M., R. D. Smissen, L. D. Shepherd, G. P. Wallis, J. J. Hayward, G. K. Chambers, C.-H. Chan, and H. Chapman. 2009. A review of genetic analyses of hybridisation in New Zealand. J. R. Soc. NZ., 39: 15-34.

Parsons, K., and L. Hermanutz. 2006. Conservation of rare, endemic Braya species (Brassicaceae): Breeding system variation, potential hybridization and human disturbance. Biol. Conserv., 128: 201-214.

Pascarella, J. B. 2007. Mechanisms of prezygotic reproductive isolation between two sympatric species, Gelsemium rankinii and G. sempervirens (Gelsemiaceae), in the southeastern United States. Am. J. Bot., 94: 468-476.

Rahmanzadeh, R., K. Müller, E. Fischer, D. Bartels, and T. Borsch. 2005. Linderniaceae and Gratiolaceae are further lineages distinct from Scrophulariaceae (Lamiales). Plant Biol., 7: 1-11.

Rajakaruna, N. 2004. The edaphic factor in the origin of plant species. Intern. Geol. Rev., 46: 471-478.

Ramsey, J. H., D. Bradshaw, J. R., and D. W. Schemske. 2003. Components of reproductive isolation between the monkeyflowers Mimulus lewisii and M. cardinalis (Phymaceae). Evolution, 57: 1520-1534.

Reeves, R. D., and A. J. M. Baker. 2000. Metal-accumulating plants. In I. Raskin, and B. D. Ensley (Eds.). Phytoremediation of Toxic Metals, pp. 193-221. Wiley, New York.

Rhymer, J. M., And D. Simberloff. 1996. Extinction by hybridization and introgression. Annu. Rev. Ecol. Evol. Syst., 27: 83-109.

RiCE, W. R. 1989. Analyzing tables of statistical tests. Evolution, 43: 223-225.

RieseberG, L. H. 1991. Hybridization in rare plants: insights from case studies in Cercocarpus and Heliantbus. In D. A. Falk, and K. E. Holsinger (Eds.). Genetics and Conser vation of Rare Plants, pp. 171-181. Oxford University Press, New York.

Rieseberg, L. H., ANd N. C. Ellstrand. 1993. What can morphological and molecular markers tell us about plant hybridization? Crit. Rev. Plant Sci., 12: 213-241.

Rieseberg, L. H., and S. E. Carney. 1998. Plant hybridization. New Phytol, 140: 599-624.

Saad, L., I. Parmentier, G. Colinet, F. Malaisse, M.-P. Faucon, P. Meerts, AND G. MAHY. 2011. Investigating the Vegetation-Soil Relationships on the Copper-Cobalt Rock Outcrops of Katanga (D. R. Congo), an Essential Step in a Biodiversity Conservation Plan. Restor. Ecol. doi/ 10.1111/j.1526-100X.2011.00786.x (In press).

Soltis, P. S., And M. A. Gitzendanner. 1999. Molecular systematics and the conservation of rare species. Conserv. Biol., 13: 471-483.

TAylor, S., J. M. Arnold, and N. H. Martin. 2009. The genetic architecture of reproductive isolation in Louisiana Irises: Hybrid fitness in nature. Evolution, 63: 2581-2594.

ter Braak, C. J. F., And P. Smilauer. 2002. CANOCO Reference Manual and CanoDraw for Windows User's guide. Microcomputer Power, Ithaca, NY.

Turner, N. C. 1986. Adaptation to water deficits: A changing perspective. Funct. Plant Biol., 13: 175-190.

Van Rossum, F., J. De Bilde, and C. Lefèbvre. 1996. Barriers to hybridization in calcicolous and silicicolous populations of Silene nutans from Belgium. Belg. J. Bot., 129: 13-18. 
Volis, S., AND M. BleCher. 2010. Quasi in situ: A bridge between ex situ and in situ conservation of plants. Biodivers. Conserv., 19: 2441-2454.

WARD, J. H. 1963. Hierarchical Grouping to optimize an objective function, J. Am. Stat. Assoc., 58: 236-244.

Whiting, S. N., R. D. Reeves, D. Richards, M. S. Johnson, J. A. Cooke, F. Malaisse, A. Paton, J. A. C. Smith, J. S. Angle, R. L. Chaney, R. Ginochio, T. Jaffré, R. Johns, T. McIntyre, O. W. Purvis, D. E. Salt, H. Schat, F. J. Zhao, and A. J. M. Baker. 2004. Research priorities for conservation of metallophyte biodiversity and their potential for restoration and site remediation. Restor. Ecol., 12: 106-116.

Wilcock, C. C., And R. Neiland. 2002. Pollination failure in plants: Why it happens and when it matters. Trends Plant Sci., 7: 270-277.

Will, L. W., And D. Rubinoff. 2004. Myth of the molecule: DNA barcodes for species cannot replace morphology for identification and classification. Cladistics, 20: 47-55.
WiLSON, P. 1992. On inferring hybridity from morphological intermediacy. Taxon, 41: 11-23.

Wolf, P. G., D. R. Campbell, N. M. Waser, S. D. Sipes, T. R. Toler, and J. K. Archibald. 2001. Tests of pre- and postpollination barriers to hybridization between sympatric species of Ipomopsis (Polemoniaceae). Am. J. Bot., 88: 213-219.

Woodruff, D. S. 2001. Declines of biomes and biotas and the future of evolution. Proc. Nat. Acad. Sci., 98: 5471-5476.

Zhang, J. J., Q. G. Ye, X. H. Yao, and H. W. Huang. 2010. Spontaneous interspecific hybridization and patterns of pollen dispersal in ex situ populations of a tree species (Sinojackia xylocarpa) that is extinct in the wild. Conserv. Biol., 24: 246-255. 